\title{
Several Problems on the Implementation of Fiduciary Guarantee Execution on Four Automotive Financing Companies after the Constitutional Court Decision Number 18/PUU-XVII/2019
}

\author{
Ning Adiasih ${ }^{1}$, Ho Lioeng Min $^{2}$, Suci Lestari ${ }^{3}$ \\ \{ning.a@trisakti.ac.id ${ }^{1}$, lioeng.min@gmail.com², sucilestari@trisakti.ac.id ${ }^{3}$ \} \\ Universitas Trisakti, Jakarta, Indonesia ${ }^{1,2,3}$
}

\begin{abstract}
The execution of a fiduciary guarantee on the vehicle financing practice often creates problems even though the position of the recipients of the fiduciary guarantee is strong, as mentioned in Indonesia's Law No. 42/1999. If the agreement is broken, the execution of the fiduciary guarantee can be carried out in three ways: (1) the execution through the executorial title, (2) the sale of the object of the fiduciary guarantee, and (3) the sale under the hand based on an agreement between the giver and the recipient of the fiduciary. After the Constitutional Court Decision No. 18/PUU-XVII/2019 is issued, there are additional provisions, namely agreement on the broken promise which needs to be included and voluntary submission concerning the object of fiduciary. This study was conducted on four automotive financing companies after the Constitutional Court Decision No. 18/PUU-XVII/2019, whose implementation was different. The type of this study was normative legal research with a descriptive approach. In addition, the data used were secondary data which were analyzed qualitatively. The results of the study can be concluded that (1) there are different interpretations of the regulations of the execution of fiduciary guarantees, (2) there are requirements that are difficult to fulfill, and (3) there are contradictions in several court decisions. The recommendations offered are that technical guidelines need to be made to support legal certainty in the execution of fiduciary guarantees.
\end{abstract}

Keywords: fiduciary guarantee; execution

\section{Introduction}

A financing company is a financial service institution that is often contacted when people need financing facilities for purchasing automotive vehicles. The current operation of the financing company's business refers to the Financial Services Authority Regulation No. 35/POJK.05/2018 concerning the Implementation of the Financing Company's Activities. In accounts payable activities, as the case mentioned previously, it often requires a handover of debt guarantee from the party borrowing money (the debtor) to the party lending money (the creditor). The debt guarantee can be in the form of (1) material guarantee, which gives 
material rights to the guarantee holder, and/or (2) individual guarantee, in the form of a debt guarantee promise. Material guarantees have "material" characteristics in the sense of giving precedence over certain objects and have the inherent nature of following the object in question. Meanwhile, individual guarantees do not give precedence over certain objects but are only guaranteed by a person's assets through the person who guarantees the fulfillment of the engagement in question [1].

Material guarantees that are still valid today in Indonesia are as follows.

a. Pawn, as regulated in Chapter 20 Book II of the Indonesian Civil Code.

b. Mortgages on ships and aircraft, as regulated in Chapter 21 Book II of the Indonesian Civil Code.

c. Mortgages, as regulated in Indonesia's Law No. 4/1996.

d. Fiduciary Guarantee, as regulated in Indonesia's Law No. 42/1999 [1].

Meanwhile, for the individual guarantees, they are as follows.

a. Insurer (borg), a person who can be billed.

b. Liability, which is similar to joint responsibility.

c. Guarantee agreement.

In automotive vehicle financing activities, the finance company secures its credit risk by imposing a fiduciary guarantee and registering the fiduciary guarantee at the fiduciary registration office based on the provisions of the laws and regulations concerning fiduciary guarantees. Indonesia's Law No. 42/1999 concerning Fiduciary Guarantees (Fiduciary Law) is intended to:

a. accommodate the needs of the community regarding the regulation of fiduciary guarantees to assist business activities and to provide legal certainty to interested parties,

b. provide convenience for the parties who use it, especially for the fiduciary providers,

c. provide legal certainty to interested parties, in which the registration of fiduciary guarantees provides priority to the fiduciary recipient over other creditors, and

d. provide guarantees to the fiduciary recipient and parties who have an interest in the guaranteed object.

Paragraph 1 of Article 1 of the Fiduciary Law explains that fiduciary is the transfer of ownership of an object based on trust provided that the object whose ownership rights are transferred remains in the control of the owner of the object. In the event of a default, the holders of the material guarantee (separatist-preferred creditors) can choose how to pay off their receivables (execution) in several ways, namely as follows [2].

a. Selling the guaranteed object under their authority or what is then called the Parate execution.

b. Using the executorial title through the fiat of the Head of the District Court as stipulated in the provisions of Article $224 \mathrm{HIR} / 258 \mathrm{Rbg}$ concerning the Grosse deed execution.

c. Selling under the hand based on the agreement of both parties to get a higher selling price.

The Fiduciary Law also emphasizes the position of the recipient of the fiduciary guarantee as to the holder of the material guarantee so that if the debtor or fiduciary provider is in breach of contract, the execution of the object of the fiduciary guarantee can be carried out by (a) implementing the executorial title, (b) selling the object of the fiduciary guarantee under the authority of the fiduciary recipient through a public auction and collect the receivables from the sales results, (c) conducting underhand sales based on an agreement between the fiduciary giver and recipient if, in this way, the highest price can be obtained that benefits the concerned parties [3]. In addition, the Indonesian National Police issued Regulation of the Head of the Indonesian National Police No. 8/2011 concerning Securing the Execution of Fiduciary Guarantees. In the preamble, the considerations for the stipulation of this regulation are as 
follows [4].

a. The Indonesian National Police is an instrument of the state.

b. The police are those whose duty and function are to maintain public security and order, law enforcement, protection, and service to the community.

c. As a state instrument, the Indonesian National Police is authorized to assist in securing the implementation of court decisions or the execution of fiduciary guarantees, activities of other agencies, and community activities.

d. The execution of the fiduciary guarantee has the same binding legal force as a court decision that has permanent legal force, thus requiring security from the Indonesian National Police.

e. Based on the considerations as referred to in letters $a, b$, and c, it is necessary to stipulate a Regulation of the Head of the Indonesian National Police concerning Securing the Execution of Fiduciary Guarantees.

Based on the case for the examination of the Fiduciary Law against the 1945 Constitution of the Republic of Indonesia, which was submitted by Aprilliani Dewi and Suri Agung Prabwowo, the Constitutional Court handed down the Constitutional Court Decision No. 18/PUU-XVII/2019, with the following verdicts.

a. For Article 15 Paragraph 2 of the Fiduciary Law concerning fiduciary security (State Gazette of the Republic of Indonesia of 1999 No. 168 and Supplement to the State Gazette of the Republic of Indonesia Number 3889), the phrase "executory power" and the phrase "equal to a court decision which has permanent legal force" are contrary to the 1945 Constitution of the Republic of Indonesia and do not have binding legal force as long as it is not interpreted "with respect to fiduciary guarantees which have no agreement on breach of contract (default) and the debtor objected to voluntarily surrendering the object that is the fiduciary guarantee, then all legal mechanisms and procedures in the execution of the Fiduciary Guarantee Certificate must be carried out and applies the same as the execution of court decisions that have permanent legal force."

b. For Article 15 Paragraph 3 of Indonesia's Law No. 42/1999 concerning Fiduciary Security (State Gazette of the Republic of Indonesia of 1999 No. 168 and Supplement to the State Gazette of the Republic of Indonesia Number 3889), the phrase "breach of promise" is contrary to the 1945 Constitution of the Republic of Indonesia and has no binding legal force as long as it is not interpreted "the existence of a breach of contract is not determined unilaterally by the creditor but on the basis of an agreement between the creditor and the debtor or on the basis of legal remedies that determine that a breach of contract has occurred."

c. For the Elucidation of Article 15 Paragraph 2 of Indonesia's Law No. 42/1999 concerning Fiduciary Security (State Gazette of the Republic of Indonesia of 1999 No. 168 and Supplement to the State Gazette of the Republic of Indonesia Number 3889), the phrase "executory power" is contrary to the 1945 Constitution of the Republic of Indonesia and has no binding legal force as long as it is not interpreted "with respect to fiduciary guarantees in which there is no agreement on breach of contract and the debtor objected to voluntarily surrendering the object that is the fiduciary guarantee, then all legal mechanisms and procedures in the execution of the Fiduciary Guarantee Certificate must be carried out and applies the same as the execution of court decisions that have permanent legal force."

With the issuance of the Constitutional Court Decision above, the automotive vehicle financing companies also experience several operational obstacles in the execution of fiduciary guarantees, namely as follows. 
a. It is not yet clear whether the agreement regarding default as stated in the articles in the Credit Agreement at the beginning fulfills the provisions of an agreement on default as referred to in the Constitutional Court Decision above.

b. The requirement, that the debtor voluntarily surrenders the object that becomes the fiduciary guarantee, is a condition that is not always encountered in the practice of executing fiduciary guarantees in the field.

c. With this Constitutional Court Decision, the Parate execution procedure with the assistance of the police becomes more difficult to carry out. The execution of fiduciary guarantees tends to go through a procedure for applying for an execution determination in court which takes a longer time and a higher cost burden.

d. Considering that the object of fiduciary security is generally in the form of movable objects that are easy to transfer, a longer execution procedure will reduce the level of certainty of execution.

\section{Research Problem}

How is the execution of fiduciary guarantees by automotive vehicle financing companies in the event that the fiduciary guarantee provider defaults after the Constitutional Court Decision No. 18/PUU-XVII/2019? What problems arise in its execution?

\section{Methods}

This study was normative legal research with a case approach. In addition, the data used were secondary data which were analyzed qualitatively.

\section{Discussion}

\subsection{The Execution of Fiduciary Guarantees by Automotive Vehicle Financing Companies}

Constitutional Court Decision No. 18/PUU-XVII/2019 stipulates that execution and sale of power by creditors is not permitted if there is no agreement on fiduciary guarantees on breach of contract (default) and debtors object to voluntarily submitting objects that become fiduciary guarantees so that all mechanisms and legal procedures in the execution of the Fiduciary Guarantee Certificate must be carried out and apply the same as the execution of court decisions that have permanent legal force, namely through the procedure for determining the execution by the District Court. It is feared that the decision will affect the operations of automotive vehicle financing companies, as previously stated, namely as follows.

a. It is not yet clear whether the agreement regarding default as stated in the articles in the Credit Agreement at the beginning fulfills the provisions of an agreement on default as referred to in the Constitutional Court Decision above.

b. The requirement, that the debtor voluntarily surrenders the object that is the fiduciary guarantee, is a condition that is not always encountered in the practice of executing fiduciary guarantees in the field.

c. The Parate execution procedure with the assistance of the police becomes more difficult to carry out. The execution of fiduciary guarantees tends to go through a procedure for 
applying for an execution determination in court which takes a longer time and a higher cost burden.

d. Considering that the object of fiduciary security is generally in the form of movable objects that are easy to transfer, a longer execution procedure will reduce the level of certainty of execution.

e. It increases potential bad loans on loans with fiduciary guarantee objects.

The total execution of 4-wheeled vehicle fiduciary guarantees in Jakarta based on data from PT Adira Dinamika Multi Finance is as follows.

Table 1. Before the Constitutional Court Decision: July to December 2019

\begin{tabular}{cccc}
\hline $\begin{array}{c}\text { Sales by } \\
\text { company/month }\end{array}$ & $\begin{array}{c}\text { Direct } \\
\text { execution/month }\end{array}$ & $\begin{array}{c}\text { Total Execution Determination } \\
\text { by District Court }\end{array}$ & $\begin{array}{c}\text { Total Guarantee } \\
\text { Execution }\end{array}$ \\
\hline 153 & 15 & 2 & 169 \\
\hline
\end{tabular}

Table 2. After the Constitutional Court Decision: January to March 2020

\begin{tabular}{cccc}
\hline $\begin{array}{c}\text { Sales by } \\
\text { company/month }\end{array}$ & $\begin{array}{c}\text { Direct } \\
\text { execution/month }\end{array}$ & $\begin{array}{c}\text { Total Execution Determination } \\
\text { by District Court }\end{array}$ & $\begin{array}{c}\text { Total Guarantee } \\
\text { Execution }\end{array}$ \\
\hline 125 & 6 & 0 & 131 \\
\hline $\begin{array}{c}\text { Sales by } \\
\text { company/month }\end{array}$ & $\begin{array}{c}\text { Direct } \\
\text { execution/month }\end{array}$ & $\begin{array}{c}\text { Total Execution Determination } \\
\text { by District Court }\end{array}$ & $\begin{array}{c}\text { Total Guarantee } \\
\text { Execution }\end{array}$ \\
\hline $19 \%$ & $61 \%$ & & $23 \%$ \\
\hline
\end{tabular}

From the three tables above, regarding the execution of fiduciary guarantees for the period July 2019 - March 2020 above, it can be concluded as follows.

a. The execution of fiduciary guarantees is generally carried out by (a) underhand sales made based on the agreement of the creditor and debtor and (b) direct/independent execution.

b. The execution of fiduciary guarantees through the determination of execution by the District Court is very little done.

c. After the issuance of the Constitutional Court Decision No. 18/PUU-XVII/2019, underhand sales made based on the agreement of creditors and debtors have decreased by $19 \%$.

d. After the issuance of the Constitutional Court Decision No. 18/PUU-XVII/2019, independent executions with the assistance of the competent authorities (in accordance with the Regulation of the Head of the Indonesian National Police No. 8/2011 concerning Security of Execution of Fiduciary Guarantees) has decreased by $61 \%$.

e. In total, the successful execution of fiduciary guarantees has decreased by $23 \%$.

Based on interviews with automotive vehicle financing business actors, the number of executions of fiduciary guarantees (based on Indonesia's Law No. 42/1999) by motor vehicle financing companies has decreased by an average of $10 \%-20 \%$ in the first quarter of 2020 (interview results with Mr. Denny Riza Farib, Chairman of the Risk Management Committee of the Association of Indonesian Financing Companies on May 26, 2020). The decline in the successful execution of fiduciary guarantees after the Constitutional Court Decision No. 18/PUU-XVII/2019 also occurs a lot in the underhand sales carried out based on the agreement between creditors and debtors. This tends to show the loss of good faith from some debtors as referred to in Article 1338 and Article 1339 of the Indonesian Civil Code.

Article 1338: "All agreements made in accordance with the law apply as law to those who make them. This agreement cannot be withdrawn other than by agreement of both parties, or 
for reasons determined by law. Approval must be carried out in good faith."

Article 1339: "Agreement does not only bind what is expressly stipulated in it but also everything according to the nature of the consent according to justice, custom, or the law." The making of a Credit Agreement or Financing Agreement must be based on the principle of good faith and promises must be kept so that the Financing Agreement can be implemented by taking into account the rights of creditors and debtors in order to provide benefits and advantages. Legal certainty in the Financing Agreement is a manifestation of an agreement to keep promises that have been mutually agreed upon. Adhering to the principle of good faith by creditors and debtors in making a Financing Agreement is a principal thing to prevent disputes due to one of or both parties not carrying out their obligations or experiencing a breach of contract [5].

Hikmahanto Juwana in his article entitled "Challenges of Legal Reform in Indonesia" conveys a quite interesting view that Indonesian people belong to a non-law-minded society. In a society that is not law-oriented, the law may not work as expected. The law is even considered a symbol that does not need to be obeyed [6].

In the deliberations of the assembly in the Constitutional Court Decision No. 18/PUUXVII/2019, it is stated explicitly that Article 15 of Indonesia's Law No. 42/1999 does not reflect the provision of balanced legal protection between the parties bound in the fiduciary agreement and also the object being fiduciary guarantees, especially regarding the occurrence of a breach of contract and transfer of property rights. Therefore, debtors need to be given rights and opportunities to make a rebuttal and/or self-defense. These considerations essentially highlight the "fairness aspect" of Indonesia's Law No. 42/1999.

In contrast to the considerations above, Charles Himawan, in his article in Harian Kompas regarding debtors who have bad credit at financial institutions, says that "What must be protected is not only the debtor but also the bank and depositors. If such awareness is not visible, there will be a tendency to overprotect the debtor [7]." For financial institutions as creditors, the execution of guarantees is actually the last choice of action to save credit or financing assets in maintaining the continuity of the company's operations and accountability to shareholders and owners of funds/depositors who put their funds in the company. In general, the execution of fiduciary guarantees, including automotive vehicle guarantees, will cause losses because the value of the proceeds of execution usually does not cover the value of the debtor's debt. As a result, the possibility of the creditor, to intentionally execute the fiduciary guarantee, if there is no default from the debtor according to the agreement, is very small.

The accumulation of excessive protection tendencies towards debtors as feared by Charles Himawan, in a society that is not law-oriented as expressed by Hikmahanto Juwana, causes a loss of "good faith" from some debtors to directly comply with the provisions agreed in the Financing Agreement in the event of default and wait for further dispute resolution process based on existing legal procedures. The decline in the successful execution of fiduciary guarantees after the Constitutional Court Decision No. 18/PUU-XVII/2019, when examined from the principle of legal certainty according to Lon Fuller, is related to the following things.

a. There is an obligation that is difficult to fulfill, namely the condition of voluntary surrender if the creditor wants to execute the fiduciary guarantee independently.

b. There is a contradiction with the previous provisions so that the competent authorities (in this case, the police) tend to ask for proof of the determination of the execution from the District Court, rather than assisting the implementation of the Parate executions based on Indonesia's Law No. 42/1999 and the Regulation of the Head of the Indonesian National Police No. 8/2011 concerning Securing the Execution of Fiduciary Guarantees. 
The implementation of the application for execution of fiduciary guarantees through the determination of the District Court is regulated in the following provisions.

a. Article 29 of Indonesia's Law No. 42/1999 concerning Fiduciary Guarantee

b. Article 33 Paragraph 3 of Indonesia's Law No. 14/1970 concerning the Basic Provisions of Judicial Power.

c. Articles 195 - 224 of HIR or Articles 206 - 258 of RBG.

d. Administrative and Technical Guidelines for General Civil and Special Civil Courts, Book II, 2007 Edition - Supreme Court of the Republic of Indonesia, pages 93 - 94. The order of operations is as follows.

a. The creditor submits an application for the execution of the fiduciary guarantee to the Head of the District Court.

b. If the request for execution is approved, the Head of the District Court will issue a stipulation of the time for summoning the debtor or determining the dunning and instructing the bailiff to send the first warning letter (Dunning 1) to the debtor in which it orders the debtor to come to court according to the stipulated time to settle arrears of financing debts to creditors. At this stage, several things arise in its implementation, namely as follows.

1) There is no provision that stipulates the time limit for examining applications for execution by the Head of the District Court. However, in general, the examination of applications by the Head of the District Court lasts for 3 to 14 days from the receipt of the application file.

2) The date and day of the summons is generally a maximum of 7 days from the determination of time of the summons.

c. If the debtor comes to court according to the time specified in the first warning letter (Dunning 1) and there is a settlement between the creditor and the debtor, the court will make an official report on the completion of the execution. Possible solutions that occur are as follows: Agreement on the time limit for the settlement of debtors' debts; The debtor pays off the debt; The debtor submits a fiduciary guarantee unit. If the debtor still refuses to make a settlement, then generally the court will give a time limit for the settlement. Moreover, if the time limit passes without any settlement, the court will issue a determination of the execution of the fiduciary guarantee units and order the bailiff to carry out the execution of the fiduciary guarantee.

d. If the debtor does not attend to fulfill the first warning letter (Dunning 1) without definite and legally appropriate notification, then the court will issue a second warning letter (Dunning 2) within a maximum of 7 days from the time specified in the first warning (Dunning 1).

e. If the debtor does not attend to fulfill the second warning letter (Dunning 2) without definite and legally appropriate notification, the court will issue a third warning letter (Dunning 3) within a maximum of 7 days from the time specified in the second warning (Dunning 2).

f. If, until the third warning letter (Dunning 3), the debtor still does not come to court, the Head of the District Court will issue a determination of the execution of the fiduciary guarantee unit and order the bailiff to carry out the execution.

g. If the execution has been carried out and the fiduciary guarantee unit is controlled by the court, the court will issue an execution auction order to conduct an auction of the fiduciary guarantee unit.

The results of this study concerning the procedure for the execution of fiduciary guarantees through the determination of the District Court are described in the following. 
1. The procedure for executing a fiduciary guarantee through a District Court decision takes a relatively long time. Considering that the object of a fiduciary guarantee is generally a movable object that is easy to transfer, a longer execution procedure will reduce the level of certainty of execution.

2. The procedure for executing a fiduciary guarantee through a District Court decision certainly requires a relatively large cost when compared to the average automotive vehicle financing debt, namely under 15 million IDR for two-wheeled vehicles and 200 million 500 million IDR for four-wheeled vehicles.

3. The success of the execution of the fiduciary guarantee is highly dependent on the good faith of the execution respondent to present the object of the fiduciary guarantee when the execution of the confiscation is carried out.

4. The procedure for executing fiduciary guarantees through a longer District Court decision with relatively large costs has caused automotive vehicle financing companies to rarely take this procedure before the presence of Constitutional Court Decision No. 18/PUU$\mathrm{XVII} / 2019$.

\subsection{The Execution of Fiduciary Guarantees in Several Court Decisions}

Gustav Radbruch states that the law has 3 aspects, namely justice, finality, and certainty. The aspect of justice refers to equal rights before the law. The aspect of finality refers to the goal of justice, which is to promote goodness in human life. This aspect determines the content of the law. Meanwhile, the aspect of certainty refers to the assurance that the law (which contains justice and norms that promote goodness) truly serves as a rule that is obeyed. It can be concluded that the first two aspects are an ideal framework of law, while the third aspect (certainty) is a legal operational framework [8].

The principle of legal certainty is actually a deduction of constitutional principles from the concept of the rule of law or what is known as the "Rule of Law" or "Rechtsstaat" [9]. According to A.V. Dicey, there are three meanings of the rule of law [10]:

1. Absolute supremacy is in the law, not in the act of wisdom or prerogative of the ruler.

2. The principle of equality applies in law (equality before the law), in which everyone must submit to the law and no one is above the law.

3. The constitution is the basis of all laws for the concerned country. In this case, the law based on the constitution must prohibit any violation of the rights and freedoms of the people.

Furthermore, Lon Fuller in his book The Morality of Law states that the legal system in a rule of law should meet the following rules [10].

1. The law must be obeyed by everyone, including the rulers of the country.

2. The law must be published.

3. The law must apply forward, not retroactively.

4. The rule of law must be written clearly so that it can be known and applied correctly.

5. The law must avoid contradictions.

6. The law does not require something that is impossible to fulfill.

7. The law must be constant so that there is legal certainty. However, the law must also be changed if the political and social situation has changed.

8. The actions of government officials and law enforcement officers must be consistent with applicable law.

The argument from Lon Fuller about the legal system is actually the meaning of the principle of legal certainty so that the principle of legal certainty is a deduction of the constitutional principles of a State of Law [9]. When examined further, the overall view of the 
rule of law always emphasizes that the rule of law is a state that bases every state life based on a clear legal mechanism and is not multi-interpretative. The law must be able to create certainty in the midst of society. If then a legal product actually gives birth to the opposite condition, namely a condition of uncertainty and multi-interpretation, then it is worth investigating further the effectiveness of the concerned legal product [11]. Moreover, Salim HS formulates legal certainty as follows [12].

1. The presence of legal clarity means that it can be easily understood by the people.

2. The rules of law do not conflict with each other.

3. Rules may not require behavior beyond the ability of legal subjects, meaning that the law may not command something that is impossible to do.

4. There is an acknowledgment from citizens in principle against the rule of law.

5. Legal certainty in court matters is characterized by an attitude of legal independence and impartiality in applying the rule of law.

Bagir Manan describes four sources of legal certainty and uncertainty, as shown in the following [13].

a. Legislation. Legislation can create or contain legal uncertainty, either because of an unfavorable or inappropriate formulation or even contradicting each other.

b. Highly sectoral policy rules. This kind of policy rule often leads to incompatibility with one or more laws and regulations.

c. Policy inconsistencies. A newly established policy can be changed immediately due to differences in views among government parties or due to pressure from outside interests.

d. The judge's decision. The judge's decision is important in realizing legal certainty. In addition, the keywords for legal certainty in the judge's decision are quick decisions and consistency of decisions.

Based on the theory of Gustav Radbruch and Lon Fuller on the principle of legal certainty and further described with the explanation of Salim HS and Bagir Manan above, the researchers discuss legal certainty in the execution of fiduciary guarantees after the Constitutional Court Decision No. 18/PUU-XVII/2019, especially from the following understandings.

1. The rule of law must be clear so that it can be applied correctly.

2. The law must avoid contradictions.

3. The law must not require something that is impossible to fulfill. Constitutional Court Decision No. 18/PUU-XVII/2019 stipulates that independent execution and sale of the object of fiduciary guarantee under the creditor's power are not permitted if there is no agreement on fiduciary guarantees regarding breach of contract (default) the debtor objects to voluntarily surrendering the object that becomes the fiduciary guarantee so that the execution of the fiduciary guarantee must be carried out through the execution determination procedure by the District Court.

The results of this study on several District Court \& High Court decisions after the issuance of the Constitutional Court Decision on 6 January 2020, to study the impact of the Constitutional Court Decision on District Court decisions, are as follows.

\section{a) High Court of Southeast Sulawesi Decision No. 50/PDT/2020/PT KDI dated 2 September 2020}

The litigants are Armia Rahayu as the appellant, previously as a plaintiff, and PT CIMB Niaga Auto Finance as the appellee, previously as a defendant. In this case, the appellant is the owner of a Toyota Avanza car with a police number DT 1612 CA 2015 which was purchased 
through a financing facility from the appellee based on the Consumer Financing Agreement dated 15 December 2015 with a loan amount of 200,242,500 IDR and a grace period for loan/credit repayment of 60 months, namely until 15 November 2020 . The number of the Fiduciary Guarantee Certificate was W27.00039536.AH.05.01 in the year 2015 .

In his lawsuit, Armia Rahayu admitted that she had entered into a financing agreement with PT CIMB Niaga Auto Finance with her vehicle as collateral. Moreover, in its implementation, she admitted that he had delayed the installment payment for 2 months. However, she objected to the withdrawal/control of the object of the guarantee by PT CIMB Niaga Auto Finance on 7 January 2020 because the object of the guarantee was withdrawn from her friend. In other words, the withdrawal violated the provisions of Article 11 of Indonesia's Law No. 42/1999 concerning Fiduciary Guarantees in conjunction with Minister of Finance Regulation No. 130/2012 in conjunction with Constitutional Court Decision No. 18/PUU-XII/2019 dated 6 January 2020. One of the considerations and the verdict is that "The fiduciary recipient (the creditor) may not carry out the execution independently but must submit an application to the District Court for its implementation."

The considerations of the panel of judges included, among other things, that the appellee's actions on 7 January 2020 in withdrawing the vehicle were not supported by evidence that there had been an agreement on breach of contract and the debtor voluntarily (no objections) submitted the object as a fiduciary guarantee. In addition, the decisions of the panel of judges are (a) declaring that the appellee's act of forcibly withdrawing the appellant's vehicle was against the law, and (b) punishing the appellee to return the appellant's vehicle and hand it back to the appellee in intact and good condition immediately after this decision has permanent legal force.

\section{b) High Court of Southeast Sulawesi Decision No. 54/PDT/2020/PT KDI dated 22} September 2020

The litigants are PT BCA Finance as the appellant, previously as a defendant, and Siti Naima Amin as the appellee, previously as a plaintiff. In this case, the appellant had been financed by PT BCA Finance for purchasing 1 (one) unit of a NISSAN car with a type of ALL-NEW MARCH 1.2 M/T, the release year of 2015, having white color a police number DT $1250 \mathrm{PE}$, as stated in the Consumer Financing Agreement with the contract number 1250009523-PK-001 dated 13 November 2015 and a Fiduciary Guarantee Certificate No. W27.00036767.AH.05.01 in the year 2015. Because of the delay in payment of installments, the defendant made a withdrawal using the services of a collection officer.

The considerations of panels of judges refer to, among others, the Constitutional Court Decision No. 18/PUU-XVII/2019 on 6 January 2020 on the provisions for the execution of fiduciary guarantees as stated in Article 15 Paragraphs 2 and 3 of Indonesia's Law No. 42/1999 concerning Fiduciary Guarantee. For this reason, the execution of the fiduciary guarantee is carried out when there is an agreement regarding the breach of contract and the willingness of the debtor to surrender the object of the fiduciary. If there is no agreement regarding the breach of contract and the debtor does not submit the object of the fiduciary voluntarily, then the procedure for the execution of the fiduciary guarantee is carried out the same as the execution of a court decision that has permanent legal force, namely by submitting a request for execution to the district court. In addition, breach of contract cannot be determined unilaterally. There must be an agreement regarding the breach of contract/default which is determined by both parties on the basis of legal remedies (lawsuits) stating that one of the parties has defaulted. The panel of judges in their decision stated that the defendant's 
act of securing the object of the fiduciary by forcibly withdrawing the plaintiff's vehicle/car from the plaintiff's garage using 2 debt collectors was an unlawful act that harmed the plaintiff.

c) District Court of Muara Bungo Decision No. 6/Pdt.G/2020/PN Mrb dated 25 June 2020

The litigants are Amrin as the plaintiff and PT Mitra Pinasthika Mustika Finance as the defendant. The plaintiff as the debtor received an automotive vehicle financing facility with the Financing Agreement No. 8952018103000073 dated 30 March 2018 for 1 unit of MITSUBISHI-FE-74 HDV CHASIS, truck type with Ps 125, the released year of 2018, amounting to $300,790,689$ IDR with the Fiduciary Guarantee Certificate No. W5,00041026.AH.05.01 dated 9 April 2018. The plaintiff admitted that the 20th month of payment was in arrears, which was due on 2 December 2019. Furthermore, the defendant as the creditor withdrew the unit on 8 January 2020.

The plaintiff stated that the defendant's act of forcibly taking the vehicle was not in accordance with the Constitutional Court Decision No. 18/PUU-XVII/2019 dated 6 January 2020, written: "For fiduciary guarantees in which there is no agreement on breach of contract (default) and the debtor objects to voluntarily surrendering the object being a fiduciary guarantee, all legal mechanisms and procedures should be based on court decisions that have permanent legal force."

The panel of judges in their consideration refers to the Financing Agreement between creditors and debtors, including the following facts.

1. The plaintiff had made a late payment or did not make a payment.

2. The defendant had issued a warning to the plaintiff.

3. In the event that the plaintiff is unable to make a payment, the defendant may terminate the agreement.

4. In the event of termination of the agreement by the defendant due to the reasons mentioned above, the defendant has the right to demand payment in full to the plaintiff.

5. In the event that the plaintiff is unable to carry out the demand for payment of the debt in full, the defendant has the right to withdraw the object of the fiduciary guarantee.

Based on the considerations that refer to the Financing Agreement, the debtor's claim was rejected.

\section{d) High Court of Tanjungkarang Decision 36/PDT/2020/PT TJK dated 6 May 2020}

The litigants are PT BFI Finance Indonesia as the appellant, previously as a defendant, and Drs. Hj. Abdul Murod as the appellee, previously as plaintiff. The plaintiff has received a financing facility from the defendant for 1 unit of a truck with a type of Mitshubishi Colt FE74 Super Speed 125 PS Bak Kayu. The number of the Financing Agreement was 4131700557 dated 11 August 2017 and the number of the Fiduciary Guarantee Certificate was W9.0007412.AH.05.01. The obligation to pay in installments was 23 times, in which the plaintiff stopped making payments since the 16th payment period which was due on 12 December 2018. For this reason, PT BFI Finance Indonesia withdrew the vehicle which was the object of the fiduciary guarantee. In the first instance court, PT BFI Finance Indonesia was declared to have committed an unlawful act because the execution of fiduciary guarantees had to be carried out with fiat from the Head of the District Court.

The considerations of the panel of judges at the appeal level are as follows. 
1. The appellant, previously as a defendant, and appellee, previously as plaintiff, are bound by a financing agreement with a fiduciary guarantee.

2. For the delay in payment, the appellant, previously as a defendant, has given a warning letter to the appellee, previously as plaintiff.

3. The fiduciary holder is given the authority to sell the object of fiduciary guarantee under personal power through a public auction (Article 15 Paragraph 3 in conjunction with Article 29 Paragraph 1 Letter b of the Fiduciary Law).

4. The Constitutional Court Decision No. 18/PUU-XVII/2019 basically does not annul the provisions of Article 15 Paragraph 3 regarding selling the object of fiduciary guarantee under personal power. However, the Constitutional Court Decision only requires a breach of contract which will be the basis for selling under personal power that will be contrary to the constitution when determined unilaterally by the creditor.

5. In the Financing Agreement, a clause has been agreed which basically contains if the appellee, previously as plaintiff defaults, the appellant, previously as a defendant, may withdraw the object of the fiduciary agreement.

6. The status and position as a preferred creditor is a general legal principle that applies if in practice it is easy to be deviated or broken by a lawsuit so that it will be feared that people or creditors will no longer believe in such status and eventually it will have an impact on disruption of the economic cycle due to slow lending.

Based on the considerations above, the panel of judges of the High Court overturned the decision of the District Court and stated that the actions of PT BFI Finance Indonesia were not against the law. From the four court decisions above, the important thing that can be concluded is that there is no common understanding in interpreting the Constitutional Court Decision No. 18/PUU-XVII/2019 in 2 important matters, namely as follows.

1. If there is no agreement on breach of contract (default) and the debtor objected to voluntarily surrendering the object as a fiduciary guarantee, then the execution of the Fiduciary Guarantee Certificate must be carried out through court fiat.

2. The existence of a breach of contract is not determined unilaterally by the creditor but on the basis of an agreement between the creditor and the debtor or on the basis of legal remedies that determine that a breach of contract has occurred. The High Court of Southeast Sulawesi Decision No. 54/PDT/2020/PT KDI dated 22 September 2020 in its consideration stated that "breach of promise" cannot be determined unilaterally. There must be an agreement regarding breach of contract/default determined by both parties on the basis of the lawsuit which states that one of the parties has defaulted. Meanwhile, the District Court of Muara Bungo Decision No. 6/Pdt.G/2020/PN Mrb dated 25 June 2020 and the High Court of Tanjungkarang Decision No. 36/PDT/2020/PT TJK dated 6 May 2020 refer to the provisions in the Financing Agreement that were agreed at the time of initial signing when interpreting the occurrence of an agreement on breach of contract.

From the difference in consideration of the decision, it is implied that the Constitutional Court Decision No. 18/PUU-XVII/2019 may create legal uncertainty in the execution of fiduciary guarantees, which is caused by differences, especially in interpreting the agreement regarding the breach of the contract referred to in the decision. In line with Lon Fuller's view, Salim HS formulates legal certainty, among others, as follows. "The existence of legal clarity means that it can be easily understood. It must not require behavior beyond the ability of the legal subject, meaning that the law must not command something that is impossible to do, and does not contradict each other [13]The results of this study, concerning the various court decisions above when associated with the Constitutional Court Decision and the principle of legal certainty, can be described as follows. 
a. The agreement on breach of contract which is one of the important conditions of the Constitutional Court Decision needs to be further defined to not cause different interpretations as in the example of the court decisions above.

b. Several different meanings regarding the terms of the "agreement on breach of contract", among others, are (a) that these conditions have been automatically fulfilled because they have been stated in the Financing Agreement agreed upon by the debtor and creditor in the beginning, (b) that these conditions must be fulfilled on when the fiduciary recipient will carry out the execution of the fiduciary guarantee, and (c) that the agreement regarding the breach of contract is determined by both parties on the basis of legal remedies (lawsuits) stating that one of the parties has defaulted. Those differences in meaning are also reflected in the different considerations of judges in several court decisions.

c. The presence of inconsistent judges' decisions in relatively the same cases also reflects the legal uncertainty that occurs.

As stated by Bagir Manan, the judges' decision in realizing legal certainty is highly important. Furthermore, the keywords of legal certainty in the judges' decisions are immediate decisions and consistency of decisions [13].

1. The conditions for submitting fiduciary guarantees voluntarily are conditions that are difficult to obtain at the time of direct execution so that the possibility of this condition being fulfilled is very small.

2. Considerations in the High Court of Tanjungkarang Decision No. 36/PDT/2020/PT TJK dated 6 May 2020 states that the status and position of a preferred creditor is a general legal principle that applies. For this reason, if, in practice, it is easy to be distorted or broken by the existence of a lawsuit, the creditor will no longer believe in the status. Therefore, it eventually will have an impact on disrupting the economic cycle due to slow lending. The Constitutional Court Decision No. 18/PUU-XVII/2019 essentially reduces the possibility of the fiduciary recipient carrying out independent execution (the Parate execution) so that it seems inconsistent with the general legal principles of the fiduciary recipient as a preferred creditor.

In the previous description above, it has been stated that the considerations of the panel of judges concerning the Constitutional Court Decision No. 18/PUU-XVII/2019 state firmly that Article 15 of Indonesia's Law No. 42/1999 does not reflect the provision of balanced legal protection between the parties bound in a fiduciary agreement and on objects that become fiduciary guarantees, especially regarding the occurrence of a breach of contract and transfer of property rights. Therefore, debtors need to be given rights and opportunities to rebut and/or defend themselves. These considerations essentially highlight the "fairness aspect" of Indonesia's Law No. 42/1999.

Gustav Radbruch admits that there is always a conflict between the three aspects of legal understanding mentioned above, namely between justice, finality, and legal certainty. Radbruch's new view of the relationship between justice and legal certainty needs to be considered. Because legal certainty must be maintained for the sake of security in the country, positive law must always be obeyed even if its contents are unfair or not in accordance with the purpose of the law. However, there must be exceptions, namely when the conflict between the contents of the legal system and justice becomes great and the legal system appears unfair. At that time, the legal system may be released [14].

Legal uncertainty in the execution of fiduciary guarantees at this time is due to several rules that cannot be fulfilled properly, namely as follows. (1) The legal rules must be clear so that they can be applied correctly. (2) The law must avoid contradictions. (3) The law does not require something that is impossible to fulfill. These three things are part of the legal system 
which, according to Lon Fuller, reflects the principle of legal certainty in a rule of law.

Although this study finds legal uncertainty in the execution of fiduciary guarantees, especially for creditors or fiduciary recipients, this Constitutional Court Decision has permanent legal force so that it must be a guideline for the execution of fiduciary guarantees, especially for automotive vehicle financing companies. Therefore, for the implementation of the principle of legal certainty in the execution of fiduciary guarantees after the Constitutional Court Decision No. 18/PUU-XVII/2019, the decision needs to be supplemented with subsequent laws and/or further technical guidelines to support legal certainty in carrying out the execution of the fiduciary guarantee.

\section{Conclusion and Recommendations}

\subsection{Conclusion}

1. Execution of a fiduciary guarantee by automotive vehicle financing companies, in the event that the fiduciary guarantee provider defaults, is generally carried out by (a) conducting underhand sales made based on the agreement of the creditor and debtor, and (b) conducting independent execution (the Parate execution). The procedure for executing a fiduciary guarantee through a District Court decision takes a relatively long time, a relatively large cost, and the risk of execution uncertainty because the object of a fiduciary guarantee is generally in the form of movable objects that are easy to transfer, causing automotive vehicle financing companies to rarely take this procedure. The Constitutional Court Decision No. 18/PUU-XVII/2019 has the effect of decreasing the success of the execution of fiduciary guarantees due to a decrease in agreements for underhand sales. Furthermore, it has the implication of the loss of the Parate mechanism.

2. Problems that arise in the execution of fiduciary guarantees after the Constitutional Court Decision No. 18/PUU-XVII/2019 dated 6 January 2020 are the emergence of the differences, especially in interpreting the requirement that "the existence of a breach of contract is not determined unilaterally by the creditor but on the basis of an agreement between the creditor and the debtor or on the basis of legal remedies which determine that a breach of contract has occurred." This requirement must be met in relation to Article 15 Paragraphs 2 and 3 of Indonesia's Law No. 42/1999 concerning Fiduciary Guarantees. There are several different interpretations of these terms, including as follows. (a) These conditions have been automatically fulfilled because they have been stated in the Financing Agreement agreed upon by the debtor and creditor in the beginning. (b) These conditions must be fulfilled when the fiduciary recipient will carry out the execution of the fiduciary guarantee. (c) The agreement regarding the breach of contract is determined by both parties on the basis of legal remedies (lawsuits) stating that one of the parties has defaulted. Those differences in meaning are also reflected in the different considerations of judges in several court decisions. The Constitutional Court Decision No. 18/PUUXVII/2019 dated 6 January 2020 also provides a condition for the execution of fiduciary guarantees according to Article 15 Paragraph 2 of Indonesia's Law No. 42/1999, namely that the debtor submits voluntarily the object that becomes the fiduciary guarantee. This requirement is difficult to obtain completely based on the operational experience of automotive vehicle financing companies. The results of the study also found legal uncertainty in the execution of fiduciary guarantees, especially for creditors or fiduciary recipients, because several rules are not fulfilled, including as follows. (1) The rule of law 
must be clear so that it can be applied correctly. (2) The law must avoid contradictions. (3) The law must not require something that is impossible to fulfill. These three things are a reflection of the principle of legal certainty referred to by Lon Fuller, Gustav Radbruch, Salim HS, and Bagir Manan, and become a reference in this study. The Constitutional Court Decision has permanent legal force so that it must be a guideline for the execution of fiduciary guarantees, especially for automotive vehicle financing companies. Therefore, the decision needs to be supplemented with subsequent laws and/or further technical guidelines in order to support legal certainty in the implementation of the execution of the fiduciary guarantee.

\subsection{Recommendations}

There is a need for a Circular Letter of the Supreme Court of the Republic of Indonesia, which confirms the meaning and definition of "agreement on breach of contract" and "voluntarily surrender the object that becomes fiduciary guarantee" in the Constitutional Court Decision No. 18/PUU-XVII/2019. As a result, it can be used as a guide for the judiciary at every level in adjudicating disputes related to the execution of fiduciary guarantees.

There is a need for Technical Administrative and Judicial Guidelines issued by the Supreme Court of the Republic of Indonesia, which are specifically related to the determination of the execution of fiduciary guarantees, by taking into the following accounts.

1. Speed in terms of time, from application to determination and execution of fiduciary guarantees.

2. Efficient in the sense that the costs required are balanced with the value of the fiduciary guarantee to be executed.

3. Effective in the sense of taking into account the condition that the object of the fiduciary guarantee is generally in the form of movable objects that are easy to transfer so that the procedure for determining and implementing the execution of a fiduciary guarantee, that is complicated and long, will reduce the level of certainty of the execution.

\section{References}

[1] S. H.S., Perkembangan Hukum Jaminan di Indonesia. Depok: Rajawali Press, 2017.

[2] D. Y. Witanto, Hukum Jaminan Fidusia dalam Perjanjian Pembiayaan Konsumen. Bandung: CV Mandar Maju, 2015.

[3] DPR, "Undang-Undang No 42/1999 Tentang Jaminan Fidusia," Jdih, no. 1, pp. 1-5, 2004, [Online]. Available: https://www.google.com/url?sa=t\&rct=j\&q=\&esrc=s\&source=web\&cd=1\&cad=rja\&u act $=8 \& v e d=2$ ahUKEwjWxrKeif7eAhVY fysKHcHWAOwQFjAAegQICRAC\&url=htt ps\%3A\%2F\%2Fwww.ojk.go.id\%2Fid\%2Fkanal\%2Fpasarmodal\%2Fregulasi\%2Fundang-undang\%2FDocuments\%2FPages\%2Fundang-undangnomo.

[4] Perkap, "Peraturan Kapolri No 8 Tahun 2011," pp. 1-11, 2011.

[5] C. N. Toar, "Prosedur Penyelesaian Hukum Perkara Cidera Janji oleh Debitur dalam Perjanjian Kredit,” J. Lex Soc., vol. VI, no. 2, pp. 135-136, 2008.

[6] H. Juwana, "Tantangan Reformasi Hukum di Indonesia - Peranan Hukum dalam Pembangunan Ekonomi," Universitas Trisakti, 2020.

[7] Charles Himawan, "Penyebab Utama Kredit Macet," Harian Kompas Edisi 5-6, Aug. 
1993.

[8] B. L. Tanya, Y. N. Simanjuntak, and M. Y. Hage, Teori hukum: Strategi Tertib Manusia Lintas Ruang dan Generasi. Yogyakarta: Genta Publishing, 2010.

[9] P. Popelier, "Legal Certainty and Principles of Proper Law Making," J. Law Reform, vol. 2, no. 3, p. 325, 2000.

[10] M. Fuady, Teori Negara Hukum Modern. Bandung: Refika Aditama, 2011.

[11] J. Simamora, "Kepastian Hukum Pengajuan Kasasi Oleh Jaksa Penuntut Umum Terhadap Vonis Bebas," vol. 7, no. 1, pp. 1-17, 2014, [Online]. Available: https://jurnal.komisiyudisial.go.id/index.php/jy/article/viewFile/90/74.

[12] S. H.S. and E. S. Nurbani, Penerapan Teori Hukum pada Penelitian Disertasi dan Tesis - Buku Kedua. Depok: Rajawali Pers, 2015.

[13] B. Manan, Menegakkan Hukum - Suatu Pencarian. Jakarta: Asosiasi Advokat Indonesia, 2009.

[14] Theo Huijbers, Filsafat Hukum dalam Lintasan Sejarah. Yogyakarta: Kanisius, 1982. 